IFN Working Paper No. 958, 2013

Globalization of Monitoring Practices: The Case of American Influences on the Dismissal Risk of European CEOs

Lars Oxelheim and Trond Randøy 
Forthcoming in Journal of Economics and Business, special issue on corporate governance.

\title{
Globalization of monitoring practices: The case of American influences on the dismissal risk of European CEOs
}

\author{
Lars Oxelheim* and Trond Randöy ${ }^{+}$
}

March, 2013

\begin{abstract}
This study examines globalization of monitoring practices by focusing on how American (U.S.) influences on European firms impact the dismissal risk for these firms' CEOs. Specifically, we argue that the stronger short term orientation of the American corporate governance system increase the dismissal performance sensitivity faced by European CEOs, indirectly and directly. The former materializes via European firms cross-listing on U.S. exchanges, the latter results from European firms hiring U.S. independent board members. Both influences are expected to result in increased dismissal performance sensitivity. Based on data from the 250 largest European publicly traded firms we find a significant increase in the dismissal sensitivity of poorly performing companies with American board members and a support for migration of American executive pay practice. However, no significant increase in dismissal performance sensitivity was identified from U.S. cross-listing. In line with our agency theory based prediction, this indicates an institutional contagion driven by the presence of U.S. board members on European corporate boards. To policy makers the message is that internationalization of boards should not be banned or restricted, since it provides owners with more options to influence the corporate governance of the firm.
\end{abstract}

JEL classification: G15, G18, G32, M14, M16, M52

Keywords: executive pay, CEO dismissal, performance sensitivity, foreign board membership

*Research Institute of Industrial Economics, Stockholm and Lund Institute of Economic Research, Lund, Sweden

+ School of Management, University of Agder, Norway

Acknowledgement: Financial support was provided by the NASDAQ OMX Nordic Foundation. 


\section{INTRODUCTION}

Fundamental differences exist between corporate governance systems around the world (e.g., Denis \& McConnell, 2003; La Porta, de Silanes \& Shleifer, 1999). Such differences are found in the CEO compensation field (Fernandes et al, 2008, Murphy, 2012) where some differences in compensation may reflect differences of CEO dismissal risk (Oxelheim \& Randøy, 2005). Among the four main corporate governance systems; the Anglo-American system, the German system, the Latin system and the Japanese system (see e.g. Shleifer \& Vishny, 1997; Goergen, 1998), some will argue that the U.S.-based AngloAmerican corporate governance system is the most demanding one (Lucier, Schuyt \& Handa, 2004), where poor performance is more likely to lead to CEO dismissal. We argue that the strong link between firm performance and CEO pay is one unique characteristic of the corporate governance system in the United States. This difference is also highlighted by the fact that U.S. boards tend to be much more involved in making governance decisions, such as CEO hiring/firing, than European boards (Bonini, Alkan and Salvi, 2012). The aim of this paper is to explore how possible firm-based influence from the U.S. corporate governance system impact CEO dismissal practice among European companies.

The Americanization ${ }^{1}$ of the corporate governance systems may take two major routes: one via legislation (and then followed by institutional changes) and another via corporate actions (Coffee, 2002). In this study we focus on the latter route. We analyze European companies and the influence on dismissal performance sensitivity following from their exposure to the U.S. corporate governance system. We analyze the influence following from two kinds of effort to do this; to actually comply with

\footnotetext{
${ }^{1}$ We use the term American and Americanization in this paper in relation to the U.S. - as Canadian corporate governance have strong elements from both the U.S. and the U.K.
} 
the U.S. system (cross-listing) and to signal compliance by recruiting at least one independent U.S. board member.

It is commonly argued that globalization of the firm produces a more complex task environment for top management (e.g. Finkelstein \& Boyd, 1998; Sanders \& Carpenter, 1998). In this paper we claim that the compliance with the American corporate governance system means a new monitoring regime for the complying firm which also implies increased dismissal performance sensitivity. An indirect support for this is found in Oxelheim \& Randøy (2005), who observed higher compensation to CEOs of nonAmerican firms with Anglo-American listing and/or board influence. They argue that European CEOs exposed to American corporate governance may anticipate their higher risk exposure (heavily penalized for a performance shortfall), and thus demand a risk premium and a higher salary. Specifically, the higher compensation of America over European CEOs reflects that the American corporate governance system is less tolerant of poor firm performance - and more likely to dismiss the CEO (Lucier, Schuyt \& Handa, 2004).

Furthermore, the greater CEO dismissal performance sensitivity generates an internationalization cost that has been neglected in the literature. This cost reflects CEOs' reduced job security, an increased likelihood of shorter tenure, and a potentially negative impact on the reputation of the incumbent in case of dismissal. Countries with a relatively low level of CEO turnover can expect to face higher levels of CEO dismissal performance sensitivity as their firms become exposed to monitoring and regulations from financial markets with less turnover tolerance for poor performance (i.e., the case of American financial markets).

In the empirical part of the paper we study CEO turnover among the 250 largest European publicly traded firms in 2004. In line with the arguments of Hall \& Gingerich (2009) we do not expect the effect of financial globalization to be uniform. Thus, we see the need to address financial internationalization (in the form of American influence in our case) on firm-level outcomes (CEO 
dismissals). With due attention to missing observations, we investigate 270 succession events over a four year period between 2000 and 2004. We study the likelihood that such events will be forced, and thus involuntary (and not that the dismissal event occurs in the first place), given that the firm has significant American influence (through American board membership or American exchange listing). We find a significant increase in the dismissal sensitivity in poorly performing companies with American board membership whereas no significant increase is found from cross-listing in the U.S. Our result supports the presence of American members on the boards of European firms as a channel for migration of U.S. governance practice to Europe.

The paper is organized in the following way. In Section 2 we review past studies on dismissal performance sensitivity, and present the research question. Theoretically we base our study on agency theory and managerial power. In Section 3 we propose two research hypotheses to be tested, followed by Section 4 in which we describe the European data and focus on key binary relationships. In Section 5, we specify the statistical model and test the hypothesized relationships in a multivariate setting. Finally, we summarize the key findings and discuss managerial and policy implications in Section 6.

\section{DISMISSAL PERFORMANCE SENSITIVITY}

The linkage between firm-level internationalization and CEO pay has been identified by past studies, whereas the role of dismissal risk as part of this linkage has received almost no attention. Sanders \& Carpenter (1998) report a positive relationship between international sales and CEO compensation in U.S. firms, and Girma, Thompson \& Wright (2002) found a similar result for large U.K. firms. Furthermore, Oxelheim \& Randøy (2005) report a positive relationship between CEO pay and the internationalization of sales, internationalization of ownership and internationalization of board 
membership of Scandinavian firms. The present study focus on a more narrow and specific kind of international influence: The cross-border American influence on European CEOs' dismissal risk.

Whereas the direct linkage between performance and dismissal/turnover has been addressed in past research (e.g. Chakraborty, Sheikh \& Subramanian, 2009; Jensen \& Murphy, 1990), the moderating effect of firm level internationalization has not. Specifically, our center of attention is on the dismissal performance sensitivity, and how this sensitivity of European firms is moderated by influences from American practice via two vehicles; American stock exchange listing or inclusion of an American board member.

Agency theory provides a normative approach to the role of executive incentives (including pay and risk factors) as a corporate governance mechanism. Managerial incentives should bridge the gap between the interest of managers versus the interest of owners (e.g. Fama \& Jensen, 1983), and empirical U.S.-based evidence shows that strong incentives (stock options in general) produce higher firm productivity (Bulan, Sanyal \& Yan, 2010). The implication is that companies should be paying CEOs with more incentive-based pay than the supply and demand of executive talent would suggest (e.g. Jensen \& Murphy, 1990). We argue here that agency theory also provides the underlying rationale for the increased CEO dismissal performance sensitivity related to the internationalization of the firm. Past research has identified a specific pay premium for Scandinavian CEOs being exposed to AngloAmerican board members and foreign regulatory authorities (Oxelheim \& Randøy, 2005). We suggest that part of this pay premium is a compensation for the stronger relationship between performance and dismissal among firms exposed to such international (American in our case) corporate governance monitoring.

The managerial power and managerial entrenchment literature suggests that the governance of corporate behavior may deviate from the normative perspective of agency theory (for an overview see Bebchuk \& Fried, 2006). U.S.-based research indicates that some CEOs have been able to build a power 
base that weakens - or even isolates the CEO - from shareholder demands (Boyd, 1994; Zajac \& Westphal, 1996). Specifically, Allgood \& Farrell (2000) found that CEO tenure (a proxy for managerial power) moderates the relation between firm performance and CEO turnover. They found that entrenched CEOs are less exposed to performance-forced dismissals. We argue that globalization of the firm affects the potential for CEO entrenchment.

\section{HYPOTHESES}

The point of departure of this paper is that the American corporate governance system, particularly during the early 2000s, is to be seen as the most demanding and unforgiving corporate governance system in the world (Lucier, Schuyt \& Handa, 2004). This view is based on factors such as a high risk of dismissal, a focus on short-term (quarterly) results, and a high degree of transparency vis-a-vis investors. After the outbreak of the financial crisis in 2008 - the weaknesses of the American corporate governance system have been highlighted but that debate is beyond this paper. We argue that the more demanding the corporate governance system, the less the degree of freedom for the CEO. The most frequently used form of corporate governance in Europe is the insider or control-oriented system (Berglöf, 2000; La Porta, de Silanes \& Shleifer, 1999). In this corporate governance system the emphasis is on the ability of large shareholders to monitor corporate behavior (Angblad, Berglöf, Högfeldt \& Svancar, 2001), as opposed to the American system where monitoring is exercised by a market for corporate control and institutional monitoring (e.g. SEC and stock exchanges). In line with this, we suggest that CEOs in firms in non-American countries that move closer to the American system of corporate governance will face increased dismissal performance sensitivity due to institutional contagion.

We emphasize two specific firm activities that signal to the international investor community compliance with an American standard of monitoring corporate behavior. Cross-listing in an American 
stock market is one of these activities. Recruitment of at least one independent board member representing a more demanding corporate governance system, i.e. the American system is the other. These activities open the way for an institutional spill-over effect that enhances the CEOs pay while simultaneously increases his/her risk of involuntary dismissal. Signals of this kind imply an upgrading of the corporate governance monitoring compared with that provided solely by the domestic system.

\subsection{Cross-listing and dismissal performance sensitivity}

International cross-listing is a generally recognized way of breaking away from a domestic capital market (e.g., Foerster \& Karolyi, 1999; Miller, 1999; Salva, 2003; Doidge, Karolyi \& Stulz, 2004). Cross-listing implies that the firm will be scrutinized by a new international investor clientele; it will be exposed to new regulatory authorities, and it will need to comply with new standards with regards to disclosure and accounting. We suggest that cross-listing in American markets exposes the CEO to higher career risks and rewards. For most firms from semi-segmented capital markets, excluding the few companies that already enjoy an international cost of capital, an American stock exchange listing is a big step, for which the firms concerned have historically been rewarded with a higher market value (Modén \& Oxelheim, 1997; Stulz, 1999). However, it should be noted that such rewards have been substantially reduced recently - and even in some cases become a liability (Marosi \& Massoud, 2008). Part of the possible value-creation arising from such an American cross-listing is captured by the CEO (rent-sharing) who possesses the scarce set of skills necessary for a successful cross-listing (Oxelheim \& Randøy, 2005). We argue that the new regulatory environment and the new investor clientele envisaged at the listing on the U.S. financial market will confront the CEOs with harsher monitoring implying increased dismissal performance sensitivity.

Hypothesis 1: For European firms there is a positive relationship between a cross-listing in the U.S. and the CEO's dismissal performance sensitivity. 


\subsection{Outsider American board members and dismissal performance sensitivity}

Corporate governance research recognizes the essential role of the board of directors in sustaining an effective organization (OECD, 1999; Jensen, 1993). Oxelheim \& Randøy (2005) show that for Scandinavian firms with one or more independent American board members the CEO of such a firm receives a significantly higher compensation than a $\mathrm{CEO}$ of a firm without a board member of that kind. One of their explanations of this finding is the signal these companies send out about being open for a harsher American styled monitoring. Consequently, CEOs in such a position will be exposed to a clash between two corporate governance cultures, and the reconciliation of the two systems will pose new challenges and tasks for them. Among other things this may call for a new corporate language (Piekkari, Randøy and Oxelheim, 2010), new internal reporting requirements, new investor-relation activities (Useem, 1998) and a higher dismissal risk. When combined with the lower tolerance for poor performance (particularly the emphasis on quarterly results), characterizing the American corporate governance system, the dismissal performance sensitivity will change.

Hypothesis 2: For European firms there is a positive relationship between the presence of a least one outsider American board member of these firms and the CEO's dismissal performance sensitivity.

\section{DATA}

\subsection{Data sources}

We have chosen to study large European publicly traded firms and the CEO successions of these firms. The reason for the choice of only large firms is the access to relevant information. The crucial classification of successions into different categories heavily relies on the information published in newspapers and magazines. Only larger firms are in general covered by the media. Moreover, our explanatory variable, "cross-listing on U.S. stock exchanges", is also dependent on published 
information. Since smaller firms may opt for ADR level-1 or over-the-counter listing, with less demanding financial reporting and disclosure requirement, we argue that the choice of large firms is further motivated. However, the choice of only larger firms comes at the expense of fewer observations. This forces us to household with our degrees of freedom by making a thorough analysis of missing values.

Data was collected for the 250 largest (by market capitalization in 2004) European publicly traded firms during the time period of 2000-2004. The study is based on the population of CEO succession events as reported in the financial media (e.g. Financial Times). Data on these events and linked performance data were collected and reported by Booz Allen Hamilton (until 2004). Specifically, they measure firm performance ("total stock return") in relation to the stock performance o firms' industry peer group, one year prior to the dismissal event. Information regarding independent American board membership (defined as American citizens) and the cross-listing of European firms on American markets has either been collected from Annual Reports, company web pages, or solicited through direct contact with the firms. The definition of all variables used in the study is given in the Appendix A1.

\subsection{Descriptive statistics}

In the period of our study (2000-2004), 270 succession events occurred among the largest 250 European companies. As shown in Table 1, these CEO succession events are distributed over fourteen EU countries. Only $7 \%$ of the succession cases reported involved European firms from non-EU countries like Norway, Switzerland and the Russian Republic. Approximately $41 \%$ of the 270 CEO succession events occurred in British companies, while $14 \%$ of all succession cases happened in companies located in Germany and $10 \%$ in French companies. Hence, observations from those three countries account for $65 \%$ of all observations. 


\section{Insert Table 1 about here}

The dismissal events appear in a broad range of industries. The group "Industrials" is the biggest group whereas "Energy" is the smallest in terms of turnover events. However, in relation to how many firms there are in each industry in our material the probability changes substantially. The circumstances surrounding each turnover case were researched and characterized by one of 11 categories listed in Table 2.

\section{Insert Table 2 about here}

Each category reflects a more or less precise reason for the CEO succession. On average the event firms have a small negative return (-2.4\% stock return one year leading up to the event) over and above the one of other firm in the same industry - but the spread in return is high (standard deviation of $22 \%) .^{2}$ The descriptive analysis shows that in about $27 \%$ of our succession cases the information available about them were (by outside observers) interpreted as being indicative of a turnover due to "poor performance". ${ }^{3}$ This modal category contains cases in which a CEO is simply fired by the board or

\footnotetext{
${ }^{2}$ We use industry adjusted returns rather than regional adjusted returns (using regional stock indices). The arguments are twofold: First, the regional/national markets are closely integrated in Europe and little discriminating effect could be expected from using regional adjustment. Second, the industry adjusted return could be expected to have a strong discriminating effect as opposed to regional adjusted return. This is particularly the case since we look at the largest 250 firms in Europe, that commonly have more activity abroad than in their home markets (cases like Volvo, Nokia, Volkswagen, Siemens, Alcatel, etc).

${ }^{3}$ The categorization is provided by Booz Allen Hamilton with reliability checks carried out by the authors.
} 
forced out of the position in a more subtle way. Almost $24 \%$ of the recorded successions were characterized as planned successions, events which were known to happen (due to contractual arrangements or retirement). The third dominant category is constituted by succession events which happen in the course of a merger. A connection to takeover or merger activity was established in more than $24 \%$ of the recorded events. The events associated with one of these three categories account for $75 \%$ of the total number of cases.

For the purpose of our CEO succession study we introduce a simple dichotomy based on the relatively fine grid of reasons exhibited in Table 3. We need to distinguish events in which a decision unit (integral part of the company, e.g. the board) decides to remove the CEO from his position due to motives (unplanned developments) related to the company and implements the decision in one way or another against the preferences of the CEO. Such circumstances are thought of as a forced succession. If a CEO leaves to take a comparable position in another company, she/he implements her/his preferences. Such cases are referred to as unforced (by an internal force) in the sequel. Note that the death of a CEO hardly constitutes voluntary change in the leadership. But since it is not forced by an exogenous force such events are classified as unforced. The distribution of succession events in a dichotomous way is given in Table 3 .

\section{Insert Table 3 about here}

After selecting the succession cases which are not related to merger activity, we can rely on a total of 204 dismissal cases. Each of our succession cases can be classified as either a dismissal (forced succession) or a voluntary one. Since M\&A's may be undertaken for disciplining or management performance reasons, they may sometimes appear to fit the criteria for a forced succession. However, mergers/takeovers are in the grey area between forced and voluntary dismissal. We extensively made 
tests for the robustness of the classification - specifically that the results are robust to variation in definitions of the grey area of mergers/takeovers (tests not reported)

The basic descriptive statistics for all relevant variables are given in Table 4. We list the number of observations used in the computation of the respective estimate(s) for each variable in the second column of the table. An $n$ less than 204 indicates the presence of missing values for the variable at hand.

We have also registered the age of CEOs involved in the succession events. We managed to collect CEO age from 266 of the 270 succession event - which vary between the ages of 28 and 75 . The youngest CEO, Jonas Birgerson, was affiliated with a Swedish information technology firm (Framfab). He was removed from his position in the course of a merger (acquisition) episode in 2000. The two CEO successions which involved 75 year old individuals were both planned. In the case of the British hardware company Farnell PLC, Morton Mandel served as an interim CEO for six month, while in the other case Hans-Joachim Langmann retired from the CEO position, (Vorstandsvorsitzender) at the pharmaceutical company Merck after holding that position for 30 years.

Insert Table 4 about here

Based on our study we can expect a CEO involved in a succession event to be about 56 years old (standard deviation of 7.2). Half of our age observations lie between 52 and 61, i.e. are distributed over $19 \%$ of the range. The skewness measure of -.54 indicates an asymmetrical age distribution, i.e. the age distribution is skewed to the left and the CEO variable is not normally distributed. The non-normal distribution has specifically been a consideration in the choice of analysis. CEO tenure varies between slightly more than a month (interim positions) and 43 years. The latter case is Calisto Tanzi the chairman and founder of the Italian company Parmalat who was dismissed at the age of 65 due to poor performance in 2003. Based on our sample we can expect a CEO to be in his ("her" in only one case!) 
position for 6 years before he (she) is replaced. The median duration on the job is 1.2 years lower: in $50 \%$ of all cases an individual served more than 4.8 years as CEO before the position was filled by a successor. We observe that $74 \%$ of the sample firms have an American stock exchange listing, but only 18\% have an American board member. Furthermore, the correlation between the two main independent variables, American board membership and American exchange listing, is only 0.1 - and not significant.

\subsection{The missing data problem}

Complete data records for all the included variables (including control variables) are available on only 165 of the 204 cases. There are no missing values for the dependent variable (dismissal). However, the same statement holds only for a subset of the independent variables. Only the indicator variable U.S. exchange listing and the categorical variables country grouping and industry category are complete. All other variables have missing observations for certain cases. There is only one case in which we do not have an observation on CEO tenure. But the information about the presence of at least one U.S. board member is not available on $9 \%$ (19 cases) of the records.

With close to $20 \%$ of our succession cases being incomplete together with a shortage of degrees of freedom, we first have to make clear that the apparent lack of data will not have any adverse effects when estimating models involving the variables given in Table 5. The theory distinguishes between three types of missing data which are more or less ominous for an analysis; missing complete at random (mcar); missing at random (mar) and "missing not at random" (mnar). The last alternative is the worst. However, in practice, cases with at least one missing value on it are often simply discarded. To see whether this so-called complete case analysis is admissible from a statistical point of view we need to establish the type of "missingness" prevalent in our data. In the case of mar and mnar, a complete case analysis will imply inefficient and biased estimators of the model parameters. If one can establish the mcar case, then the estimates obtained using complete case analysis are still going to be inefficient but unbiased (van der Heijden, Donders, Stijnen \& Moons, 2006; Little, 1992). With respect to likelihood 
based inference, Rubin (1976) has demonstrated that likelihood ratios are invariant to discarding of incomplete records in the mcar case. Fortunately, it is possible to test if data are mcar on the basis of the sample. We do not report the analysis of the missing data but have concluded from our test that missing data are of mcar-kind implying that using a complete case analysis will not trigger a bias in our estimators.

\section{MODEL AND RESULTS}

To provide a framework which allows us to test the hypotheses motivated in Section 3, we chose a binary response type model. In our context, the probability for the event that a CEO succession is forced as opposed to voluntary is modeled as a non-linear function of risk factors. After stating the model explicitly, we discuss some aspects concerning statistical inference. Two alternative specifications of the model are introduced and the estimation results are presented.

\subsection{The binary response model}

We consider the dichotomous random variable $\mathrm{Y}$ taking the value 1 if a succession case is a dismissal. If the succession is voluntary then the variable assumes the value 0 . It is assumed that the discrete random variable $\mathrm{Y}$ follows a Bernoulli distribution depending on the parameter $\mathrm{p} \in(0,1)$, the probability of dismissal. Moreover, we assume that there exists a non-linear functional relationship between the dismissal probability and a set of independent variables represented by the elements of the vector $\mathrm{z}$, i.e. $\mathrm{p}=\mathrm{F}(\mathrm{Oiz})$, where $\mathrm{F}$ is monotonically increasing function and $\mathrm{O}$ denotes a parameter vector of appropriate dimension. Under these assumptions the binary random variable Y follows the Bernoulli distribution: 
$\mathrm{Y} \sim \mathrm{B}(\mathrm{F}(\mathrm{Oiz}))=\mathrm{F}(\mathrm{Oiz}) \mathrm{y}(1-\mathrm{F}(\mathrm{Oiz})) 1-\mathrm{y} \mathrm{I}\{\mathrm{O}, 1\}(\mathrm{y})$

where $\mathrm{I}\{\mathrm{O}, 1\}$ denotes the indicator function. Hence

$\mathrm{E}[\mathrm{Y} \mid \mathrm{Z}=\mathrm{z}]=\mathrm{p}=\mathrm{F}(\mathrm{Oiz})$

represents the (non-linear) regression of the random variable $\mathrm{Y}$ on the explanatory variables listed in $\mathrm{z}$.

\subsection{Specification of the model}

Two specifications of the binary response model (1) are discussed below: the logistic specification and the probit specification. In our case, there is no substantive information available which would let us choose between the two alternatives a priori. We chose to consider both to see whether our results are invariant under alternative specifications. We employ the specifications of the binary response model (1) to test the hypotheses concerning the relationship between the dismissal probability p and U.S. exchange listing (Hypothesis 1), as well as the relation between p and U.S. board membership (Hypothesis 2).

In order to avoid the misspecification of the statistical model, that might produce unreliable estimates, we base our theoretical analysis on Harrel, Lee, Matchar \& Reichert (1985). They conclude that such problems can be avoided if the ratio of the number of outcome events to the number of explanatory variables (EVP-ratio) lies between 10 and 20. These results were clearly supported in an extensive simulation study by Peduzzi, Concato, Kemper, Holford \& Feinstein (1996). Following their guidelines and taking our data situation into consideration, we should not include more than ten explanatory variables when modeling the probability of the event "forced succession".

As a result of a structured exploratory modeling phase involving all potential explanatory variables introduced in Section 3, it became clear that the variables CEO tenure and market value could be eliminated from the variable pool. Moreover, controlling for all other important factors the industry categories were never found to be significant. 
It is possible that sole industry adjusted stock performance (one year prior to the event) does not have a significant main effect on the probability of dismissal, but the effect of the total stock return varies with some characteristics of the succession case or the nature of the environment in which the case is embedded. To account for such interaction effects we introduce the two interaction terms; U.S. exchange listing $\times$ return and U.S. board membership $\times$ return into the model (a term over and above the first order term). These interaction terms constitute the variables $z 9$ and $z 10$. The resulting logit and probit version of model (2) is estimated using the maximum likelihood (ML) approach.

\subsection{Estimation Results}

Prior to performing the ML estimation procedure we assessed whether the sufficient condition for the existence, finiteness and uniqueness of estimates as given by Albert \& Anderson (1984, Theorem 3, p.7) is fulfilled. A numerical check confirmed that our data exhibits the pattern referred to as overlap, implying that the sufficient condition holds. As could be expected in such a case, we observed a rapid convergence of the algorithm locating the maximum of the likelihood function under both specifications.

Insert Table 5 about here

Our ML estimation results are summarized in Table 5. At a first glance both models are valid and from a qualitative point of view the models produce identical results. There are no differences in the signs of the estimated coefficients. With respect to the statistical significance of the ML estimates, the findings are identical for the two specifications. In both cases we do not find main effects for the variables U.S. 
exchange listing and U.S. board membership but a clearly significant interaction term U.S. board membership $\times$ return. This indicates the existence of a moderator effect of U.S. board membership on the relationship between the dismissal risk and the performance variable total stock return. ${ }^{4}$ Given that Powers (2005) highlight that our model (using interaction terms in non-linear models) could be misinterpreted, we have been particular careful in terms of checking for such possible misinterpretations.

\section{DISCUSSION AND CONCLUSION}

By focusing on CEO dismissal risk, this paper addresses one aspect of internationalization of corporate governance practices across borders. The issue of CEO dismissal and CEO incentives in its extension is of great concern to public policy-makers, to investors and to regulators amid the financial crisis of the first decades of the 2000s. This is reflected in a number of corporate governance reports from the OECD, FIBV, and central banks on the one hand, and in the corporate governance guidelines from sources such as the Cadbury Commission, the Sarbanes-Oxley Act of 2002, on the other. The focus of this paper is on the influence of American corporate governance practice on dismissal performance sensitivity in European firms. We argue that the recruitment of American independent member(s) to European boards and the cross-listing of European firms on U.S. stock exchanges are important financial facilitators for the migration of ideas and practices from the U.S. to European corporate governance regimes.

The applied research design provides a natural experiment on the issue of CEO dismissal and financial internationalization. By studying dismissal events, not dismissal probabilities as commonly

\footnotetext{
${ }^{4}$ We have also preformed tests where the interaction terms are tested one by one - and the results remains statistically unchanged.
} 
seen in other dismissal studies, this paper allows for a test that clearly reduces endogeneity problems on the issue of reversed causality. Furthermore, we include a set of control variables that have been included in prior studies (CEO age, industry-adjusted performance, country dummies). However, the list of control variables is of course not exhaustive, so future studies may investigate the role of control variables such as ownership characteristics (nationality, blockholders, family ownership) and variables reflecting the American board member sitting on European boards (their tenure, experience in European firms, tenure with other boards). To further check the robustness of our findings, we have applied alternative definitions to our key variables, such as using percentage rather than a binary variable for American board membership. This robustness check did not alter the results.

We study the population of succession events in the 250 largest European publicly listed firms between 2000 and 2004. Due to missing observations in relation to the independent variables (American board membership and control variables), we have some "missing observations by random". Taking a critical position with respect to our own modeling approach, we carried out extensive model diagnostics and implemented model validation routines. The procedures resulted in no evidence against the statistical model chosen.

We have found our results robust to the classification of the dismissal implications of mergers and acquisitions which are in general difficult to categorize. Moreover, we have found no impact on the dismissal relation from the Sarbanes-Oxley Act, which was implemented during the period of investigation (results not reported). We found that firm performance alone has no direct effect on the dismissal risk which is in line with a range of compensation studies that find a small and some times insignificant underlying pay-performance relationship (Tosi, Werner, Katz \& Gomez-Mejia, 2000). Finally, our country dummies indicate that the U.K. and Irish firms are significantly less likely to force CEO dismissal than firms from the Rhine-region countries. Considering that the U.K. has a corporate 
governance system and shareholder protection environments comparable to the U.S. (La Porta, de Silanes \& Shleifer, 1999) this result triggers a need for further research.

In line with our theory-based prediction, the tests in this study show that internationalization in the market for corporate control increases dismissal performance sensitivity. This indicates the presence of institutional contagion driven by American board membership on European corporate boards. However, this institutional contagion does not necessarily follow exactly the same routes for other parts of world. Transition of practices by American board members to Asian firms deserves a study of its own. We argue that the result is particularly interesting, since non-American firms are becoming increasingly concerned about the costs of American stock regulations in general and of the implementation of the Sarbanes-Oxley Act of 2002 in particular (Bartram, Stadtmann \& Wissmann, 2006; Economist, 2006).

Contrary to our predictions, the empirical results show no significant increase in dismissal performance sensitivity stemming from American stock exchange cross-listing. This effect might be due to the fact that foreign stock listing only indirectly affects boards' decision-making, and/or the fact that we only looked at the period of 2000-2004. The insignificance of the cross-listing variable may also reflect the inconclusiveness of previous research on European firms reflecting the relatively "weak" commitment in undertaking a cross-border listing as compared to the more demanding corporate action of undertaking a cross-listing and an outright equity issue on the foreign market in one go (Modén \& Oxelheim, 1997). 


\section{REFERENCES}

Albert, A. \& Anderson, J. 1984. On the Existence of Maximum Likelihood Estimates in Logistic Regression, Biometrika, 71(1), 1-10.

Allgood, S. \& Farrell, K. 2000. The effect of CEO turnover on the relation between firm performance and turnover, Journal of Financial Research, 23(3), 373-380.

Angblad, J., Berglöf, E., Högfeldt, P., \& Svancar, H. 2001. Ownership and Control in Sweden - Strong Owners, Weak Minorities, and Social Control, in The Control of

Corporate Europe, ed. by F. Barca \& M. Becht, P. 228-258. Oxford University Press, Oxford.

Bartram, S., G. Stadtmann \& Wissmann, M. 2006. Corporate transparency and risk management disclosure of European issuers in the United States, in Corporate and institutional transparency for economic growth in Europe, ed. by L. Oxelheim, p. 303-333. Elsevier, Oxford, UK.

Bebchuk, L. A., \& Fried, J. M. 2006. Pay without performance: Overview of the issues. Journal of Applied Corporate Finance, 17: 8-23.

Berglöf, E. 2000. Reforming corporate governance: redirecting the European agenda, in Corporate Governance and Globalization, ed. by S. Cohen \& G. Boyd, p. 245-274. Edward Elgar Publishing, Cheltenham, UK.

Bonini, S. Alkan, A. \& Salvi, A. 2012. The effects of venture capitalists on the governance of Firms, Corporate Governance: An International Review, 20 (1), 21-45.

Boyd, B. 1994. Board Control and CEO Compensation, Strategic Management Journal, 15, 335-344.

Bulan, L. ,Sanyal, P. \& Yan, Z. 2010. A few bad apples: An analysis of CEO performance pay and firm productivity, Journal of Economics and Business, 62, 273-306.

Carroll, R. J., Spiegelman, C. H., Lan, K. G. Bailey, K. T. \& Abbott, R. D. 1984. On Errors-in-Variables for Binary Regression Models" Biometrika, 71(1), 19-25.

Chakraborty, A., Sheikh, S. \& Subramanian, N. 2009. The relationship between incentive compensation and performance related CEO turnover, Journal of Economics and Business, 61, 295-311

Coffee, J. 2002. Racing towards the Top?: The Impact of Cross-Listings and Stock Market Competition on International Corporate Governance, Columbia Law Review, 102(7), 1757-1831.

Denis, K. \& McConnell, J. 2003. International Corporate Governance, Journal of Financial and Quantitative Analysis, 38(1), 1-36.

Doidge, C., Karolyi, G. \& Stulz, R. 2004. Why are foreign firms listed in the U.S. worth more?, Journal of Financial Economics, 71, 205-238.

Economist. 2006. "Restoring the shine", http://www.economist.com/finance/ displaystory.cfm?story id=E1 RPQRVSS. 
Fama, E. \& Jensen, M. 1983. Separation of Ownership and Control, Journal of Law and Economics, $26,301-25$.

Fernandes, N., Ferreira, M., Matos, P. \& Murphy, K.J. 2008, The Pay Divide: (Why) Are U.S. Top Executives Paid More?, mimeo, University of Southern California.

Finkelstein, S. \& Boyd, B. 1998. How Much Does the CEO Matter? The Role of Managerial Discretion in the Setting of CEO Compensation, Academy of Management Journal, 41, 179-199.

Foerster, S. R. \& Karolyi, G. A. 1999. The effects of market segmentation and investor recognition on asset prices: Evidence from foreign stocks listing in the United States, Journal of Finance, 54(3), 9811013.

Girma, S., Thompson, S. \& Wright, P. 2002. Multinational Activity and CEO Compensation: Preliminary Evidence from Large UK Firms, Weltwirtschaftliches Archiv, 138, 680-693.

Goergen, M. 1998. Corporate Governance and Financial Performance. A Study of German and UK Initial Public Offerings. Edgar Elgar, Cheltenham, UK.

Hall, P. A. \& Gingerich, D. W. 2009. Varieties of capitalism and institutional complementarities in the political economy: An empirical analysis, British Journal of Political Science, 39, 449-482.

Harrel, F., Lee, K. L., Matchar, D. B. \& Reichert, T. A. 1985. Regression models for prognostic prediction: Advantages, problems and suggested solutions, Cancer Treatment Reports, 69, 1071-1077.

Jensen, M. 1993. The modern industrial revolution, exit, and the failure of internal control systems, Journal of Finance, 48, 831-881.

Jensen, M. \& Murphy, K. 1990. Performance Pay and Top-Management Incentives, Journal of Political Economy, 98, 225-264.

La Porta, R., de Silanes, F. L. \& Shleifer, A. 1999. Corporate Ownership around the World, Journal of Finance, 54, 471-517.

Little, R. J. 1992. Regression with missing X's: A Review, Journal of the American Statistical Association, 87(420), 1227-1237.

Lucier, L., Schuyt, R. \& Handa, J. 2004. The Perils of Good Governance, Annual Studies on CEO Succession. Booz Allen Hamilton, London.

Marosi, A. \& Massoud, N. 2008. You can enter but you cannot leave...: U.S. security markets and foreign firms, Journal of Finance, LXIII (5), 2477-2506.

Miller, D. 1999. The market reaction to international cross-listings: evidence from Depositary Receipts, Journal of Financial Economics, 53, 103-123.

Moden, K. \& Oxelheim, L. 1997. Why issue equity abroad? Corporate efforts and stock market responses, Management International Review, 37(3), 223-241. 
Murphy, K.J. (2012), The Politics of Pay: A Legislative History of Executive Compensation, in Hill, J and Thomas R. (eds.) (2012), The Research Handbook on Executive Pay, Edgar Elgar Publishers, London.

OECD. 1999. OECD principles of corporate governance, Document No. SG/CG(99) 5, Organization for Economic Cooperation and Development.

Oxelheim, L. \& Randøy, T. 2003. The Impact of Foreign Board Membership on Firm Valuation, Journal of Banking and Finance, 27(12), 2369-2392.

Oxelheim, L. \& Randøy, T. 2005. The Anglo-American financial influence on CEO compensation in non-Anglo-American firms, Journal of International Business Studies, 36(4), 470-483.

Oxelheim, L., Stonehill, A., Randøy, T., Vikkula, K. Dullum, K. \& Moden, K. 1998. Corporate Strategies to Internationalise the Cost of Capital. Copenhagen Business School Press, Copenhagen.

Peduzzi, P., Concato, J., Kemper, E., Holford, T. R. \& Feinstein, A. R. 1996. A simulation study of the number of events per variable in logistic regression analysis, Journal of Clinical Epidemiology, 49(12), $1373-1379$.

Pikkari, R., Oxelheim, L. \& Randøy, T. 2010. On the diversity of Supervisory boards: Language as a cost factor in Nordic firms, Conference Paper, European International Business Association Annual meeting, Porto, Portugal.

Powers. E.A. 2005. Interpreting Logit Regressions with Interaction Terms: An Application to the Management Turnover Literature, Journal of Corporate Finance, 11 (3), 504-552.

Rubin, D. B. 1976. Inference and Missing Data, Biometrika, 63(3), 581-592.

Salva, C. 2003. Foreign listing, corporate governance, and equity valuations, Journal of Economics of Business, 55, 463-485.

Shleifer, A. \& Vishny, R. 1997. A survey of corporate governance, Journal of Finance, 52, 737-783.

Stulz, R. 1999. Globalization, corporate finance and the cost of capital, Journal of Applied Corporate Finance, 12(3), 8-25.

Tosi, H., Werner, S. Katz, J. \& Gomez-Mejia, L. 2000. How much does performance matter? A metaanalysis of CEO pay studies, Journal of Management, 26, 301-339.

Useem, M. 1998. Corporate leadership in a globalizing equity market, Academy of Management Executive, 12(4), 43-59.

van der Heijden, G. J., Donders, A. T. Stijnen, T. \& Moons, K. G. 2006. Imputation of missing values is superior to complete case analysis and the missing-indicator method in multivariable diagnostic research: A clinical example, Journal of Clinical Epidemiology, 59, 1102-1109.

Zajac, E. \& Westphal, J. 1996. Director Reputation, CEO-Board Power, and Dynamics of Board Interlocks, Administrative Science Quarterly, 41, 507-529. 
A1: Variable Definitions

\begin{tabular}{|c|c|}
\hline Variable & Definition \\
\hline CEO age & The CEO's age (years) at the time of the dismissal \\
\hline CEO tenure & The CEO's tenure (years) as CEO with the company \\
\hline Market capitalization & $\begin{array}{l}\text { Stock market value in millions of Euros at the time of } \\
\text { the dismissal }\end{array}$ \\
\hline Total stock returns & $\begin{array}{l}\text { The total stock return to investors (including dividends) } \\
\text { relative to firm's industry one year leading up to the } \\
\text { dismissal event }\end{array}$ \\
\hline US exchange listing & $\begin{array}{l}\text { The company has a US-based stock exchange listing at } \\
\text { the time of the dismissal: value of } 1 \text { if such listing exists } \\
\text { - } 0 \text { otherwise. }\end{array}$ \\
\hline US board membership & $\begin{array}{l}\text { The company has at least one independent (non-employee) } \\
\text { board member with a US citizenship: value of } 1 \text { if such } \\
\text { board member(s) exist(s) - } 0 \text { otherwise. }\end{array}$ \\
\hline US listing $\times$ return & $\begin{array}{l}\text { Interaction term between Total stock returns and US } \\
\text { exchange listing }\end{array}$ \\
\hline US board membership $\times$ return & $\begin{array}{l}\text { Interaction term between Total stock returns and US } \\
\text { exchange listing }\end{array}$ \\
\hline Country groups & $\begin{array}{l}\text { All European countries were divided into five groups: } \\
\text { (1) Anglo-Saxon := Ireland, United Kingdom } \\
\text { (2) Benelux := Belgium, Luxembourg, Netherlands } \\
\text { (3) Mediterranean := Italy, Portugal, Spain } \\
\text { (4) Nordic := Denmark, Finland, Norway, Sweden } \\
\text { (5) Rhine := France, Germany, Switzerland Rhine, } \\
\text { where (5) serves as baseline in the dummy coding scheme. }\end{array}$ \\
\hline Industry category & 2-digit industry classification \\
\hline
\end{tabular}


Table 1 Country composition of succession events

\begin{tabular}{|r|l|l|r|r|}
\hline$i$ & Country & code & absolute frequency & relative frequency \\
\hline \hline 1 & Belgium & BEL & 4 & 0.0148 \\
2 & Croch Republic & CZE & 3 & 0.0111 \\
3 & Denrnark & DEN & 4 & 0.0148 \\
4 & Finland & FIN & 6 & 0.0222 \\
5 & France & FRA & 26 & 0.0963 \\
6 & Germany & GER & 39 & 0.1444 \\
7 & Ireland & IRE & 5 & 0.0185 \\
8 & Italy & ITA & 18 & 0.0667 \\
9 & Luxcembourg & LUX & 2 & 0.0074 \\
10 & Netherlands & NLD & 17 & 0.0630 \\
11 & Partugal & POR & 0 & 0.0000 \\
12 & Spain & SPA & 9 & 0.0933 \\
13 & Sweden & SWE & 8 & 0.0296 \\
14 & United Kingdarn & UK & 110 & 0.4074 \\
\hline 15 & Narway & NOR & 5 & 0.0185 \\
16 & Russian Republic & RUS & 270 & 0.0074 \\
17 & Switzerland & SWI & & 0.0444 \\
\hline$\sum$ & & & 12 & 1.0000 \\
\hline
\end{tabular}


Table 2. Reasons for dismissal (2000-2004)

\begin{tabular}{|c|c|c|c|c|}
\hline$r$ & Resecon & sbsolute frequency & relative frexquency $(\%)$ & clasenification \\
\hline 1 & Bosard/power struggle & 26 & 9.63 & forced \\
\hline 2 & Move to lesser position & 3 & 1.11 & forced \\
\hline 3 & Poor performance & 72 & 26.67 & forced \\
\hline 4 & Desath or illness & 7 & 2.59 & voluntiary \\
\hline 5 & Interim CEO & 7 & 2.59 & voluntary \\
\hline 6 & Job demands & 3 & 1.11 & volunitiary \\
\hline 7 & Merger & 66 & 24.44 & merger \\
\hline 8 & Planned successaion & 64 & 23.70 & voluntary \\
\hline 9 & Move to another company & 16 & 5.93 & voluntary \\
\hline 10 & Earlier tenure & 0 & 0.00 & voluntiary \\
\hline \multirow[t]{2}{*}{11} & Governance change & 6 & 2.22 & voluntary \\
\hline & $\sum$ & 270 & 100 & \\
\hline
\end{tabular}

Table 3 Distribution of categories

\begin{tabular}{|c|c|l|c|c|}
\hline$i$ & Classification & ressons $(r$ in Table 3) & absolute frequency & relative frequency (\%) \\
\hline 1 & Forced & $1,2,3$ & 103 & 38.15 \\
2 & Voluntary & $4,5,6,8,9,10,11$ & 101 & 37.41 \\
\hline 3 & Merger & 7 & 66 & 24.44 \\
\hline & $\sum$ & & 270 & 100.00 \\
\hline
\end{tabular}

Table 4 Basic descriptive statistics

\begin{tabular}{|l|r|r|r|r|r|}
\hline Variable & $n$ & $\hat{\mu}$ & $\hat{\sigma}$ & $x_{(1)}$ min. & $x_{(n)} \max$. \\
\hline dismissal & 204 & .495 & .501 & .000 & 1.000 \\
\hline CEO age & 194 & 56.263 & 7.463 & 28.000 & 75.000 \\
CEO tenure & 203 & 6.356 & 5.703 & .100 & 43.000 \\
market capitalization & 202 & 10091.290 & 16221.120 & 1036.160 & 124282.700 \\
total stock returns & 190 & -.024 & .223 & -.676 & 1.027 \\
US exchange listing & 204 & .735 & .442 & .000 & 1.000 \\
US board membership & 185 & .184 & .388 & .000 & 1.000 \\
US board membership $\times$ return & 171 & -.011 & .097 & -.676 & .293 \\
US listing $\times$ return & 190 & -.025 & .181 & -.672 & 1.027 \\
\hline
\end{tabular}


Table 5 Summary table for logit and probit models

\begin{tabular}{|c|c|c|c|c|c|c|}
\hline \multirow[b]{2}{*}{ Variables } & \multicolumn{3}{|c|}{ Logit } & \multicolumn{3}{|c|}{ Probit } \\
\hline & Estimate & p-value & S-Ind. & Estimate & p-value & S-Ind. \\
\hline Const. & 11.22 & 0.000 & $* * *$ & 6.56 & 0.000 & $* * *$ \\
\hline CEO age & -0.19 & 0.000 & $* * *$ & -0.11 & 0.000 & $* * *$ \\
\hline total stock return & -0.85 & 0.610 & & -0.57 & 0.581 & \\
\hline country-group dummy 1 & -0.96 & 0.037 & $* *$ & -0.60 & 0.030 & $* *$ \\
\hline country-group dummy 2 & -2.11 & 0.013 & $* *$ & -1.27 & 0.007 & $* *$ \\
\hline country-group dummy 3 & 0.63 & 0.387 & & 0.36 & 0.391 & \\
\hline country-group dummy 4 & -1.41 & 0.060 & $*$ & -0.86 & 0.058 & $*$ \\
\hline U.S. exchange listing & 0.61 & 0.187 & & 0.36 & 0.187 & \\
\hline U.S. board membership & -0.74 & 0.224 & & -0.41 & 0.232 & \\
\hline U.S. listing $\times$ return & 0.49 & 0.805 & & 0.33 & 0.789 & \\
\hline U.S. board membership $\times$ retur & -11.94 & 0.021 & $* *$ & -7.11 & 0.020 & $* *$ \\
\hline sample size & 165 & & & 165 & & \\
\hline Log-lik. & -83.68 & & & -83.59 & & \\
\hline pseudo $\mathrm{R}^{2}$ & 0.27 & & & 0.27 & & \\
\hline
\end{tabular}

Legend: S-ind. $\equiv$ significance indicator: $*$ if $\mathrm{p}<0.10, \quad * *$ if $\mathrm{p}<0.05, * * *$ if $\mathrm{p}<0.001$

Country-group dummies: 1= Ireland, United Kingdom; 2=Belgium, Luxembourg, Netherlands; 3=Italy, Portugal, Spain; 4=Denmark, Finland, Norway, Sweden 